\title{
Tobacco price increase and consumption behaviour among male smokers in Saudi Arabia: a community-based study
}

\author{
Mohamad Al-Tannir, ${ }^{1}$ Amani Abu-Shaheen, ${ }^{2}$ Youssef Altannir ${ }^{3}$ and Mustafa Altannir ${ }^{3}$
}

${ }^{1}$ Research Monitoring Department, Research Center, Riyadh, Saudi Arabia. (Correspondence to: Mohamad Al- Tannir: maltannir@kfmc.med.sa). ${ }^{1}$ King Fahad Medical City, King Fahad Medical City, Riyadh, Saudi Arabia. ${ }^{2}$ Scientific Writing Department, Research Center, King Fahad Medical City, Riyadh, Saudi Arabia. ${ }^{3}$ Research Monitoring Department, Research Center, College of Medicine, Alfaisal University, Riyadh, Saudi Arabia.

\begin{abstract}
Background: Saudi Arabia doubled its tobacco tax in June 2017.

Aims: To examine the association between an increase in tobacco prices and consumption behaviour among current male smokers in Riyadh.

Methods: We conducted a community-based study using a self-administered questionnaire distributed to current male smokers aged 15+ years in Riyadh in 2018. The survey included questions on sociodemographic characteristics, tobacco consumption and self-reported chronic health conditions.

Results: A total of 1481 participants were included in the final data analysis. After the tobacco tax was doubled, $25.6 \%$ of the participants reduced their cigarette consumption and 1.0\% quit smoking. The average daily cigarette consumption after enforcing the tobacco tax [19.77, standard deviation (SD) 10.7], was statistically significantly lower than before taxation (21.19, SD 10.8) $(P<0.0001)$. The calculated price elasticity of demand was -0.20 (inelastic). Employment status $(P=0.002)$ and per capita gross domestic product purchasing power parity $(P=0.001)$ were the only statistically significant factors associated with the change in smoking habits.
\end{abstract}

Conclusions: Increasing tobacco prices reduced tobacco consumption by $26.6 \%$ among Saudi Arabian male smokers.

Keywords: tobacco tax, tobacco consumption, male smokers, smoking habits, Saudi Arabia

Citation: Abu-Shaheen A; Altannir Y; Altannir M. Tobacco price increase and consumption behaviour among male smokers in Saudi Arabia: a communia ty-based study. East Mediterr Health J. 2020;26(12):1518-1524. https://doi.org/10.26719/emhj.20.066

Received: 12/05/19, accepted: 30/12/19

Copyright (C) World Health Organization (WHO) 2020. Open Access. Some rights reserved. This work is available under the CC BY-NC-SA 3.0 IGO license (https://creativecommons.org/licenses/by-nc-sa/3.o/igo).

\section{Introduction}

Tobacco consumption is one of the biggest contributors to public health problems, killing approximately 7 million people worldwide each year (1). An average of 6 million deaths is attributable to the direct use of tobacco, while an average of 890000 deaths result from second-hand smoking. According to global health observational data, more than 1 billion people smoked tobacco in 2015, and nearly $80 \%$ of them lived in low- and middle-income countries (1).

In 2016, the World Health Organization (WHO) reported that the overall rate of tobacco use in Saudi Arabia among those aged 15 + years was $12.2 \%$, with a rate of $23.7 \%$ among males compared with $1.5 \%$ among females (2). In a previous survey of Saudi Arabian adolescents aged 13-15 years, the prevalence of tobacco use was $21.2 \%$ among males and 9.1\% among females (3).

Tremendous efforts have been made to reduce tobacco consumption all over the world in the form of bans on smoking in public places, anti-smoking advertising campaigns, and comprehensive tobacco control programmes (4-7).

The Gulf Cooperation Council governments provide access to smoking cessation treatments such as nicotine replacement therapy (e.g. patch, inhaler, gum). However, the availability of these smoking alternatives did not increase their utilization because of a lack of social support, costs and access constraints (8). Also, clinicians were not likely to advise patients to quit or use smoking cessation alternatives due to either time constraints with patients or inadequate training in delivering smoking cessation services (8).

Imposing taxes on tobacco products has proven to be the most effective policy to reduce tobacco use and its adverse effects on health, the economy and society (9-13). After joining the WHO Framework Convention for Tobacco Control in 2005, the Saudi Arabian Ministry of Health initiated a national tobacco control programme with remarkable efforts. Saudi Arabia announced the doubling of tobacco tax on June 10, 2017 following the decision of the Gulf Cooperation Council countries. Increasing the price of tobacco products is considered to be a highly effective policy to reduce tobacco use, which eventually decreases the associated morbidity and mortality (14). Indeed, reducing tobacco use is a key component of the Healthy People 2030 vision, part of the national action plan for improving the health of all Saudi Arabians.

This study aimed to assess the association between the tobacco price increase due to higher tobacco taxes and consumption behaviour among current male smokers in Riyadh. 


\section{Methods}

\section{Participants and questionnaire}

A community-based cross-sectional study was conducted between April and October 2018 in all 5 districts of Riyadh city (North, South, East, West, Central). Male smokers (current and those who quit after the tobacco tax increase) aged $15+$ years were eligible to participate. Males below the age of 15 years, females, and males over 15 years old who had never smoked were excluded. The study was approved by the institutional review board at King Fahad Medical City in Riyadh.

Participants were approached in coffee shops and other public places to take part in this study by completing a self-administered questionnaire that was created based on an in-depth review of the literature (3,913). Considering the age categories, the sample size was equally distributed across the 5 districts. The following procedures were followed to ensure the validity of the questionnaire. First, the literature was reviewed and previous instruments were examined to develop drafts of the questionnaire. The questionnaire was then reviewed by 4 experts in research methodology and epidemiology. Finally, to ensure the questionnaire was clear and well understood by the target population, a pilot study was conducted on 50 Saudi Arabian males aged 15+ years recruited in coffee shops and other public places. Based on the experts' recommendations and the outcome of the pilot study, a few questions were reformulated and amended to enhance the questionnaire's validity. The pilot survey data were not included in the final analysis. The reliability, measured using Cronbach's alpha, was 0.72 .

The questionnaire had 3 parts covering sociodemographic characteristics, tobacco consumption and self-reported chronic health conditions. It took an average of 10 minutes to complete.

Sociodemographic characteristics included age group, education level, marital status, employment status, and yearly income based on Saudi Arabia's gross domestic product (GDP) per capita purchasing power parity (PPP), equal to US\$ 45821 (14).

Tobacco consumption was assessed using 9 questions: opinion regarding the increase in tobacco prices, type of tobacco consumed, change in consumption behaviour based on the tax increase, change of cigarette brand to one with a cheaper price, number of cigarettes smoked before and after taxation, number of years as a smoker, place where cigarettes are purchased, price of preferred type of tobacco, and current tobacco use.

\section{Sample size estimate}

According to a 2016 census of the population of Riyadh, there were 3747557 males aged 15+ years. Given the prevalence of smoking among this population is $25 \%$, which equates to 936889 smokers aged $15+$ years. To generate a $95 \%$ confidence interval from a representative sample within a $2.5 \%$ margin of error, adjusting for the adult pop- ulation across all districts of Riyadh and considering an incomplete and non-response rate of $20 \%$, we would need a sample of 1534 male smokers. The sample collected was almost equal across the 5 districts: North 310, South 303, East 308, West 308, Central 305. The sampling frame included coffee shops that had a seated smoking area. Site visits and meetings with coffee shops managers were done in advance to acquire their approval for data collection. A convenience sample of 107 coffee shops was reviewed for eligibility; $10(9 \%)$ were determined ineligible due to the absence of an outdoor space designated for smoking. An additional 5 (4.5\%) coffee shops did not allow us to collect data on their premises. Therefore, data collection took place in 92 coffee shops: North 20, East 19, South 18, West 18, Central 17.

\section{Statistical analysis}

Demographic characteristics of study participants were reported as mean and standard deviation (SD) of a continuous variable, and categorical variables were reported as number and percentage.

Chi-squared was used to measure the association between the change in smoking habit (stopping, reducing, the average number of cigarettes per day) and the covariates, including age, marital status, education, employment status, and yearly income based on the GDP per capita PPP in Saudi Arabia (US\$ < 45821.61, $\geq 45821.61$ ). For the multivariate analysis, a backward-elimination approach in a multiple logistic regression model was performed. Odds ratios and $95 \%$ confidence intervals were reported. The correlation coefficient, the standard deviation of the coefficient, and $P$-values were reported. We used SPSS, version 22, for data analysis and accounted for the complex sampling design. A 2-tailed P-value of 0.05 was considered significant.

The effect of increasing the tobacco tax on consumption behaviour was evaluated by calculating the tobacco price elasticity.

The price elasticity of demand for tobacco was estimated using the ratio between the percent change in the quantity demanded and the corresponding percent change in price as in the formula below:

Price elasticity of demand $=$ percentage change in quantity/percentage change in price

$$
\text { Percentage change in quantity }=\left(\mathrm{Q}_{2}-\mathrm{Q}_{1}\right) /\left[\left(\mathrm{Q}_{2}+\mathrm{Q}_{1}\right) / 2\right]
$$
$\times 100$

Percentage change in price $=\left(\mathrm{P}_{2}-\mathrm{P}_{1}\right) /\left[\left(\mathrm{P}_{2}+\mathrm{P}_{1}\right) / 2\right] \times 100$

\section{Results}

The final data set included 1481 out of 1534 male participants since 53 questionnaires were excluded because of extensive missing data. A total of 694 participants (47.0\%) were in the 25-34 years age group, 821 (55.7\%) were single, and $1168(79.6 \%)$ were employed. Employment status $(P=$ $0.002)$ and GDP per capita PPP $(P=0.001)$ were the only statistically significant factors associated with a change in smoking habits (Table 1).

The most common type of tobacco used was cigarettes 


\begin{tabular}{|c|c|c|c|c|c|}
\hline \multirow[t]{2}{*}{ Characteristic } & \multicolumn{2}{|c|}{ Total } & \multicolumn{2}{|c|}{ Decreased smoking } & \multirow[t]{2}{*}{ P-value } \\
\hline & No. & $\%$ & No. & $\%$ & \\
\hline \multicolumn{6}{|c|}{ Age (years) $(n=1477)$} \\
\hline $15-24$ & 308 & 20.9 & 86 & 28.2 & \multirow[t]{5}{*}{0.278} \\
\hline $25-34$ & 694 & 47.0 & 194 & 28.0 & \\
\hline $35-44$ & 330 & 22.3 & 85 & 25.9 & \\
\hline $45-54$ & 101 & 6.8 & 18 & 18.2 & \\
\hline$>54$ & 44 & 3.0 & 10 & 22.7 & \\
\hline \multicolumn{6}{|c|}{ Education level $(n=1464)$} \\
\hline Elementary & 7 & 0.5 & 1 & 14.3 & \multirow[t]{5}{*}{0.463} \\
\hline Intermediate & 23 & 1.6 & 7 & 30.4 & \\
\hline Secondary & 139 & 9.5 & 40 & 29.0 & \\
\hline College & 1090 & 74.4 & 280 & 25.8 & \\
\hline Postgraduate & 205 & 14.0 & 63 & 31.2 & \\
\hline \multicolumn{6}{|c|}{ Marital status ( $n=1475)$} \\
\hline Single & 821 & 55.7 & 224 & 27.4 & \multirow[t]{4}{*}{0.093} \\
\hline Married & 599 & 40.6 & 160 & 26.9 & \\
\hline Divorced & 52 & 3.5 & 6 & 11.5 & \\
\hline Widowed & 3 & 0.2 & 1 & 33.3 & \\
\hline \multicolumn{6}{|c|}{ Employment status ( $n=1468$ ) } \\
\hline Employed & 1168 & 79.6 & 295 & 25.4 & \multirow[t]{2}{*}{0.02} \\
\hline Unemployed & 300 & 20.4 & 95 & 32.0 & \\
\hline \multicolumn{6}{|c|}{ GDP per capita PPP $(\$ U S)(n=1387)$} \\
\hline$<45821.61$ & 1009 & 72.9 & 288 & 28.7 & \multirow[t]{2}{*}{0.001} \\
\hline$\geq 45821.61$ & 375 & 27.1 & 77 & 20.6 & \\
\hline
\end{tabular}

$G D P=$ gross domestic product; $P P P=$ purchasing power parity.

$P<0.05$ considered significant

in 1269 (85.7\%). We found that 372 participants $(25.1 \%)$ agreed with the increased taxes on cigarettes versus 896 participants $(60.5 \%)$ who disagreed. After taxes were increased, 379 participants (25.6\%) reduced cigarette consumption and 15 (1.0\%) quit smoking. The daily mean cigarette consumption before the tax increase was 22.19 (SD 10.8) compared with 19.77 (SD 10.70) afterwards (P < 0.0001). The mean price of cigarettes before and after the tax increase was US\$ 3.68 (SD 4.59) and US\$ 6.63 (SD 4.96) respectively. Respondents' smoking characteristics are presented in Table 2: 375 (25.3\%) purchased cigarettes from both local markets and duty-free shops, and 110 (7.4\%) from duty-free shops only.

The calculated tobacco price elasticity was $(-0.20)$ :

Change in quantity $=(22.9-19.77) /(22.19+19.77) / 2 \times$ $100=14.9 \%$ $57.2 \%$

Change in price $=(6.63-3.68) /(6.63+3.68) / 2 \times 100=$

Price elasticity of demand $=11.53 / 57.22=0.20$

The demand for tobacco is, therefore, said to be price inelastic; this means that tobacco consumption behaviour is unresponsive to a change in price.

From the multivariate analysis, we determined that participants with a GDP per capita PPP below 45821.61 USD were 1.45 times more likely to stop or significantly reduce the average number of cigarettes smoked per day compared with participants with a higher GDP per capita PPP $(P=0.01)$. Employment status was also a significant factor that affected tobacco consumption behaviour among the study participants. The employed participants were less likely to stop or reduce smoking in comparison with unemployed participants (odds ratio: $0.72, P=0.04$ ) (Table 3).

\section{Discussion}

A decrease in cigarette consumption could result from reducing the number of cigarettes consumed per smoker or by reducing the number of smokers. The results of our study showed that increasing the prices of tobacco products was associated with a significant reduction in the number of cigarettes consumed by smokers.

According to our findings, a $100 \%$ increase in tobacco tax reduced tobacco consumption by $26.6 \%$ among our participants. This is consistent with previous studies documenting that increasing cigarette prices through taxation is one of the most effective methods of decreasing cigarette consumption (15-20). Several 


\begin{tabular}{|c|c|c|}
\hline Characteristic & No.a & $\% a$ \\
\hline \multicolumn{3}{|l|}{ Increase tobacco price $(n=1474)$} \\
\hline Agree & 370 & 25.1 \\
\hline Disagree & 892 & 60.5 \\
\hline No comment & 212 & 14.4 \\
\hline \multicolumn{3}{|l|}{ Type of tobacco $(n=1481)$} \\
\hline Cigarettes & 1269 & 85.7 \\
\hline Hookah (water pipe) & 128 & 8.6 \\
\hline Electronic cigarettes & 52 & 3.5 \\
\hline Cigar & 16 & 1.2 \\
\hline Pipe & 5 & 0.3 \\
\hline Other & 11 & 0.7 \\
\hline \multicolumn{3}{|l|}{ Change in consumption behaviour ( $n=1481$ ) } \\
\hline Stopped & 15 & 1.0 \\
\hline Reduced & 379 & 25.6 \\
\hline Change to a cheaper brand & 223 & 15.1 \\
\hline No change & 1087 & 73.4 \\
\hline Mean (SD) no. of cigarettes before taxation increase & 22.19 & 10.8 \\
\hline Mean (SD) no. of cigarettes after taxation increase & 19.77 & 10.7 \\
\hline Mean (SD) no. years of smoking & 12.22 & 8.5 \\
\hline \multicolumn{3}{|l|}{ Source of cigarettes $(n=1481)$} \\
\hline Local market & 979 & 66.1 \\
\hline Duty free & 110 & 7.4 \\
\hline Both & 375 & 25.3 \\
\hline Other & 17 & 1.2 \\
\hline Mean price of cigarettes pack before taxation (\$US) & 3.68 & \pm 4.59 \\
\hline Mean price of cigarettes pack after taxation (\$US) & 6.63 & \pm 4.96 \\
\hline
\end{tabular}

${ }^{a}$ Except where indicated as mean and standard deviation (SD).

countries have started to implement such taxes after these positive results were observed (19-31). Numerous studies in high-income countries have shown that a 10\% increase in cigarette prices decreases consumption by about $4 \%$ (32). Available data indicate that consumption in lowand middle-income countries is even more responsive to price. For example, estimated decreases were about 5.5\% in China, 5.2\% in Mexico, and 5.4\% in South Africa (17-19).

In economics, price elasticity is defined as the percentage change in consumption in response to a $1 \%$ change in price. The price elasticity of demand is a measure to show the responsiveness, or elasticity, of the quantity of a good or service, demanded by a given change in its price. In our study, the demand for smoking is classed as inelastic (-0.20). Inelastic demand indicates low responsiveness to price changes, which suggests that after the tax increase, cigarettes are still affordable. Future increases in cigarette prices might increase the price elasticity, which could suggest a more effective use of tax increases to control tobacco. A study employing panel data for the period 2005-2014 from Euromonitor International, the World Bank and WHO in the 28 countries of the European Union explored the effects of an increase in cigarette prices on consumption. The study showed that the price elasticity of cigarette demand varied from -0.503 to -1.227 in those countries. Countries with a per capita gross national income below US\$ 5418 had the highest cigarette price elasticity $(-1.227)$. Those with a per capita gross national income greater than US\$ 5418 exhibited less cigarette price elasticity (20). In our results, GDP per capita PPP and employment status were shown to significantly affect smoking habits among the participants. Employed participants with a higher GDP per capita PPP were less likely to stop smoking or reduce their consumption of tobacco after the tax increase. The 2 primary concerns that have been expressed relative to this tax increase were: an increase in smuggling to avoid the additional tax burden; the most common strategy for tax avoidance was purchasing cigarettes from dutyfree shops; our data showed that $25.3 \%$ of respondents purchased cigarettes from both local markets and dutyfree shops and $7.4 \%$ from duty-free shops only; and secondly, smokers switching to cheaper alternatives and lower quality tobacco products, which was expressed by $15 \%$ of our study participants.

The majority of our respondents disagreed about the 


\begin{tabular}{lccccc}
\hline $\begin{array}{l}\text { Table } 3 \text { Multivariate analysis of the statistically significant variables } \\
\text { Characteristic }\end{array}$ & Coefficient & $\begin{array}{c}\text { SD of the } \\
\text { coefficient }\end{array}$ & P-value & Odds ratio & $\mathbf{9 5 \%}$ CI \\
\hline Employed & -0.06 & 0.403 & 0.02 & 0.72 & $0.53-0.98$ \\
GDP per capita PPP \$US $<45821.61$ & 0.08 & 0.443 & 0.003 & 1.45 & $1.08-1.95$ \\
\hline
\end{tabular}

$S D=$ standard deviation; $C I=$ confidence interval.

$\mathrm{GDP}=$ gross domestic product; $\mathrm{PPP}=$ purchasing power parity.

$P<0.05$ is considered significant.

increase in the price of tobacco products. Similarly, a study conducted by Green and Gerken showed that smokers disagreed more often with increases in tobacco taxation compared to nonsmokers (29). Another study conducted by Dixon et al. reported that the relationship between income difference and support for higher tobacco sales taxes was considered minor for nonsmokers, but essential for smokers (30).

Public health authorities need to promote educational programmes to provide youth with knowledge about tobacco hazards, and to further assist and provide needed guidance and support to tobacco consumers who are willing to quit. Many policy-makers in other countries use some of the revenue produced from tobacco taxes to support anti-smoking activities. For instance, the California Tobacco Tax and Health Promotion used tobacco tax revenue to develop educational programmes to prevent and reduce cigarette use (22). In Australia, a $5 \%$ tax on the sale of tobacco products is used to support health promotion programmes (21). In Egypt and Nepal, additional tax revenues were used in health-related activities to support health care for children and lowincome families (21).

Our study is subject to certain limitations. First, smoking variables were self-reported without biomarker validation. Second, this study was done only on males as the use of addictive substances, including smoking cigarettes, is considered deviant behaviour among female Saudi Arabians. Thus, the results of this study cannot be generalized to the entire Saudi Arabian population. Finally, the reliability of the data is dependent on the respondents' recall and honesty. Underreporting of the number of cigarettes smoked before and after the tax increase could also be a significant problem.

\section{Conclusion}

Although increasing tobacco prices reduced tobacco consumption by $26.6 \%$ among Saudi Arabian male smokers, cigarette price elasticity was less than 1 . The results of the study might be important for policymakers to develop a strategic plan to adopt new measures to control smoking. Furthermore, there is a need to design and develop educational programmes to enhance the knowledge of the community regarding the negative impact of smoking on health. Future research is needed in this area, especially in the Middle East and specifically in Saudi Arabia, because published studies in this field are relatively scarce.

Funding: This study was funded by the research centre at King Fahad Medical City.

Competing interests: None declared.

\section{Hausse du prix du tabac et comportements de consommation chez les fumeurs masculins en Arabie saoudite : enquête en communauté}

\section{Résumé}

Contexte : L'Arabie saoudite a doublé sa taxe sur le tabac en juin 2017.

Objectifs : Examiner le lien entre la hausse du prix du tabac et les comportements de consommation des fumeurs masculins à Riyad.

Méthodes : En 2018, nous avons mené une enquête en communauté à Riyad en distribuant un questionnaire autoadministré à des fumeurs masculins âgés de 15 ans et plus. L'enquête comprenait des questions sur les caractéristiques sociodémographiques, la consommation de tabac et les maladies chroniques autodéclarées.

Résultats : Au total, 1481 participants ont été pris en compte dans l'analyse finale des données. Après le doublement de la taxe sur le tabac, 25,6\% des participants ont réduit leur consommation de cigarettes et 1,0\% ont cessé de fumer. La consommation quotidienne moyenne de cigarettes après l'imposition de la taxe sur le tabac (19,77; écart type : 10,7) était, d'un point de vue statistique, significativement plus faible qu'avant son imposition $(21,19$; écart type : 10,8$)(p<0,0001)$. L'élasticité-prix de la demande était de $-0,20$ (inélastique). Le statut professionnel $(p=0,002)$ et le produit intérieur brut par habitant mesuré en parité de pouvoir d'achat $(p=0,001)$ ont été les seuls facteurs statistiquement significatifs associés au changement des habitudes tabagiques.

Conclusions : La hausse des prix a réduit de $26,6 \%$ la consommation de tabac des fumeurs masculins saoudiens. 


$$
\begin{aligned}
& \text { ارتفاع أسعار التبغ والسلوك الاستهلاكي في صفوف المدخنين الذكور في الرياض: دراسة بجتمعية } \\
& \text { محمد التنير، أماني أبو شاهين، يوسف التيع ولنير، مصطفى الثنير } \\
& \text { الخلاصة } \\
& \text { الخلفية: ضاعفت المملكة العربية السعودية الضريبة التي تفرضها على التبخ في يونيو / حزيران } 2017 .
\end{aligned}
$$

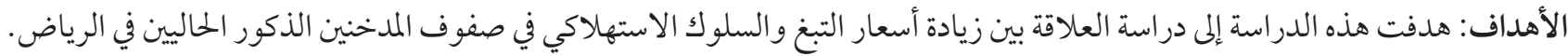

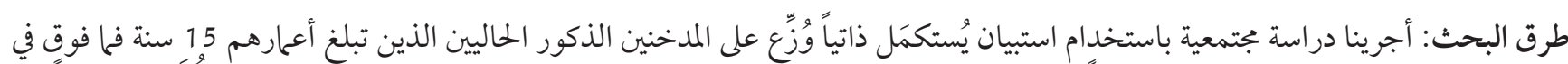

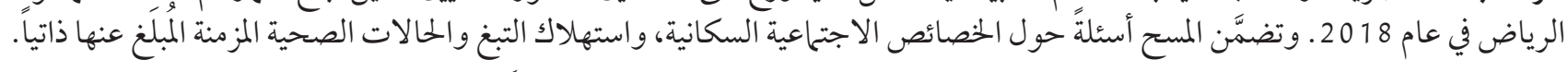

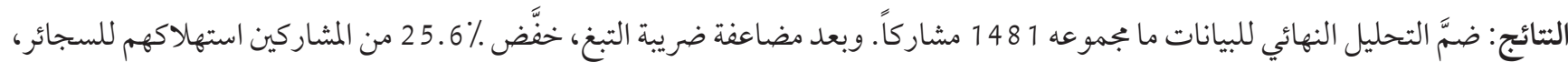

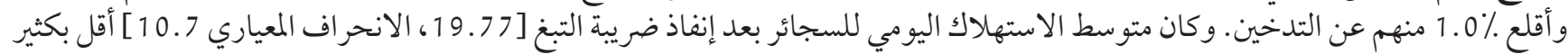

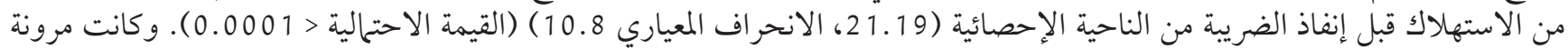

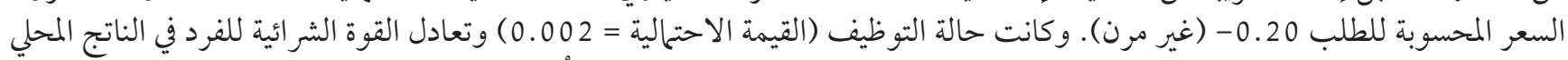

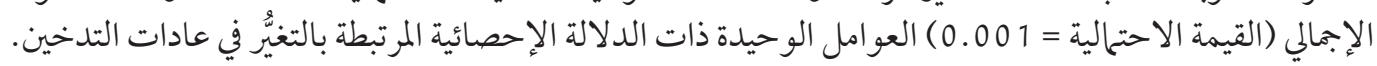

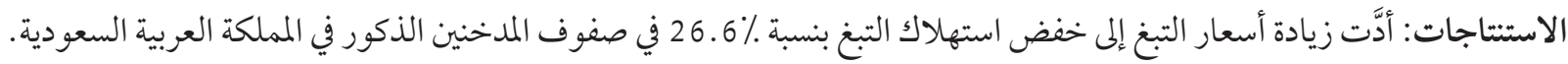

\section{References}

1. Tobacco fact sheet. Geneva: World Health Organization; 2017 (http://www.who.int/mediacentre/factsheets/fs339/en/, accessed 7 April 2020).

2. WHO report on the global tobacco epidemic. Geneva: World Health Organization; 2019 (https://www.who.int/tobacco/surveillance/policy/country_profile/sau.pdf, accessed 11 April 2020).

3. Moradi-Lakeh M, El Bcheraoui C, Tuffaha M, Daoud F, Al Saeedi M, Basulaiman M, et al. Tobacco consumption in the Kingdom of Saudi Arabia, 2013: findings from a national survey. BMC Public Health, 2015;15:611. doi:10.1186/s12889-015-1902-3

4. Dilley JA, Harris JR, Boysun MJ, Reid TR. Program, policy, and price interventions for tobacco control: quantifying the return on investment of a state tobacco control program. Am J Public Health. 2012 Feb;102(2):e22-8. doi:10.2105/AJPH.2011.300506.

5. Hu TW, Bai J, Keeler TE, Barnett PG, Sung HY: The impact of California Proposition 99, a major anti-smoking law, on cigarette consumption. J Public Health Policy. 1994;15:26-36.

6. Hu TW, Sung HY, Keeler TE: Reducing cigarette consumption in California: tobacco taxes vs an anti-smoking media campaign. Am J Public Health. 1995;85:1218-22.

7. International Agency for Research on Cancer. IARC handbooks of cancer prevention. Tobacco control. Volume 14. Effectiveness of tax and price policies in tobacco control. Lyon, France: International Agency for Research on Cancer, World Health Organization; 2011 (https://publications.iarc.fr/_publications/media/download/4018/05229a5e57f58bobf51364ddof3329d45c898839.pdf, accessed 7 April 2020).

8. Monshi S, Halpern M. Factors associated with smoking cessation and smoking cessation interventions in the Gulf Cooperation Council countries. Saudi Med J. 2019;40(2):119-25.

9. Tabuchi T, Nakamura M, Nakayama T, Miyashiro I, Mori J, Tsukuma H. Tobacco price increase and smoking cessation in Japan, a developed country with affordable tobacco: a national population-based observational study. J Epidemiol. 2016;26(1):14-21. doi:10.2188/jea.JE20140183

10. Azagba S, Burhoo P, Chaloupka FJ, Fong GT. Effect of cigarette tax increase in combination with mass media campaign on smoking behaviour in Mauritius: findings from the ITC Mauritius Survey. Tob Control. 2015 Jul;24(Suppl. 3):iii71-5. doi:10.1136/ tobaccocontrol-2014-052096

11. Lee JM, Liao DS, Ye CY, Liao WZ. Effect of cigarette tax increase on cigarette consumption in Taiwan. Tob Control. 2005 Jun;14(Suppl. 1):i71-5. doi:10.1136/tc.2004.008177

12. Yao T, Ong MK, Max W, Keeler C, Wang Y, Yerger VB, et al. Responsiveness to cigarette prices by different racial/ethnic groups of US adults. Tob Control. 2018 May;27(3):301-9. doi:10.1136/tobaccocontrol-2016-053434

13. Al-Mohrej OA, AlTraif SI, Tamim HM, Fakhoury H. Will any future increase in cigarette price reduce smoking in Saudi Arabia? Ann Thorac Med. 2014 Jul;9(3):154-7. doi:10.4103/1817-1737.134070

14. Kostova D, Chaloupka FJ, Shang C. A duration analysis of the role of cigarette prices on smoking initiation and cessation in developing countries. Eur J Health Econ. 2015 Apr;16(3):279-88. doi:10.1007/s10198-014-0573-9

15. Yong Suk L, Hong-Suk K, Hyung-Do K, Ki-Bong Y, Sung-In J, Eun-Cheol P. Is a price increase policy enough for adolescent smokers? Factors affecting the effectiveness of increasing cigarette prices among Korean adolescent smokers. Nicotine Tob Res. 2016 October;18(10): 2013-9. https://doi.org/10.1093/ntr/ntw122 
16. Hu T-w, Mao Z, Shi J, Chen W. Tobacco taxation and its potential impact in China. Paris: International Union Against Tuberculosis and Lung Disease; 2008.

17. Waters H, Sáenz de Miera B, Ross H, Reynales Shigematsu LM. The economics of tobacco and tobacco taxation in Mexico. Paris. International Union Against Tuberculosis and Lung Disease; 2010.

18. Van Walbeek C. Tobacco excise taxation in South Africa. Johannesburg: World Health Organization; 2003.

19. Yeh CY, Schafferer C, Lee JM, Ho LM, Hsieh CJ. The effects of a rise in cigarette price on cigarette consumption, tobacco taxation revenues, and of smoking-related deaths in 28 EU countries-- applying threshold regression modelling. BMC Public Health. 2017 Sep 21;17(1):676. doi:10.1186/s12889-017-4685-x

20. Hu TW: Cigarette taxation in China: Lessons from international experiences. Tob Control. 1997;6:136-40.

21. Bal DG, Kizer KW, Felten PG, Mozar HN, Niemeyer D. Reducing tobacco consumption in California. Development of a statewide anti-tobacco use campaign. JAMA. 1990 Sep 26;264(12):1570-4. PMID:2395199

22. Goldstein AO, Cohen JE, Flynn BS, Gottlieb NH, Solomon LJ, Dana GS, et al: State legislators' attitudes and voting intentions toward tobacco control legislation. Am J Public Health. 1997;87:1197-200. doi:10.2105/ajph.87.7.1197

23. Hahn EJ, Toumey CP, Rayens MK, McCoy CA: Kentucky legislators' views on tobacco policy. Am J Prev Med. 1999;16:81-8. doi:10.1016/s0749-3797(98)00134-2

24. Hahn EJ, Rayens MK: Consensus for tobacco policy among former state legislators using the policy Delphi method. Tob Control. 1999 Summer;8(2):137-40. doi:10.1136/tc.8.2.137

25. Keeler TE, Hu TW, Barnett PG, Manning WG: Taxation, regulation, and addiction: a demand function for cigarettes based on time-series evidence. J Health Econ. 1993 Apr;12(1):1-18. doi:10.1016/0167-6296(93)90037-f

26. Lanoie P, Leclair P. Taxation or regulation: looking for a good anti-smoking policy. Economics Letters. 1998;58:85-9. https://doi. org/10.1016/S0165-1765(97)00258-9

27. Jeffery RW, Forster JL, Schmind TL, McBride CM, Rooney BL, Pirie PL. Community attitudes toward public policies to control alcohol, tobacco, and high fat food consumption. Am J Prev Med. 1990 Jan-Feb;6(1):12-9. PMID:2340187

28. Pederson LL, Shelley BB, Ashley JJ. A population suvery on legistlative measure sto restric smoking in Ontario: 2. Knowledge, attitudes and predicted behavior. Am J Prev Med. 1986 Nov-Dec;2(6):316-23. PMID:3453196

29. Green DP, Gerken AE: Self-interest and public opinion toward smoking restrictions and cigarette taxes. Public Opinion Quarterly. 1989;53:1-16. https://doi.org/10.1086/269138

30. Dixon RD, Lowery RC, Levy DE, Ferraro KF. Self-interest and public opinion toward smoking policies: a replication and extension. Public Opinion Quarterly. 1991;55:241-54. https://doi.org/10.1086/269255

31. WHO technical manual on tobacco tax administration. Geneva: World Health Organization; 2010. 